\title{
POSTERIOR PENETRATING INJURY OF THE NECK: A CASE REPORT
}

\author{
Nenad Koruga ${ }^{1}$, Anamarija Soldo Koruga ${ }^{2}$, Silva Butković Soldo ${ }^{2}$ and Goran Kondža ${ }^{3}$ \\ ${ }^{1}$ Osijek University Hospital Center, Department of Neurosurgery, Faculty of Medicine, \\ Josip Juraj Strossmayer University of Osijek, Osijek, Croatia; ${ }^{2}$ Osijek University Hospital Center, \\ Department of Neurology, Faculty of Medicine, Josip Juraj Strossmayer University of Osijek, Osijek, Croatia; \\ ${ }^{3}$ Osijek University Hospital Center, Department of Surgery, Faculty of Medicine, \\ Josip Juraj Strossmayer University of Osijek, Osijek, Croatia
}

\begin{abstract}
SUMMARY - A 45-year-old male patient was admitted to the emergency unit due to posterior stab wound of the neck. The knife was directed diagonally from the left to the right side of the neck in the dorsoventral axis. The patient was fully conscious upon admission with pain and paresthesia along the upper right extremity. The patient underwent computed tomography $(\mathrm{CT})$ and $\mathrm{CT}$ angiography scan of the neck, which revealed the knife blade piercing the left sided neck muscles and through the intervertebral ligaments of the $\mathrm{C} \mathrm{IV/C} \mathrm{V}$ in direction to the contralateral internal carotid artery, vertebral artery and the $\mathrm{C} 5$ nerve root. The patient underwent an urgent surgery according to the radiographs. Electromyography was performed during the early postoperative care and revealed an acute lesion of the right-sided C5 nerve root. Postoperative follow-up magnetic resonance imaging revealed intact brachial plexus bundles at the site of injury. Symptoms of reduced muscle strength and limited range of motion of the upper right extremity prevailed. Penetrating neck injuries represent a rare entity of all trauma injuries. Meticulous preoperative radiographs revealed close proximity of the knife blade tip to the right-sided vertebral artery and common carotid artery. Limited abduction at the right shoulder during postoperative period correlated to the $\mathrm{C} 5$ nerve root injury.
\end{abstract}

Key words: Neck injuries; Radiculopathy; Signs and symptoms; Wounds, stab; Case reports

\section{Introduction}

Penetrating injuries of the neck (PNI) that have violated the platysma muscle comprise up to $10 \%$ of all trauma cases ${ }^{1,2}$. A high possibility rate of life-threatening injuries in such traumas is related to the anatomic distribution and density of vital structures in the neck ${ }^{3}$. Injury of the spinal cord in PNI accounts for less than $1 \%$ and is widely related to low-velocity injuries such as stab wounds ${ }^{4}$. The authors describe a rare injury of the neck inflicted by knife and directed in dorsoventral axis. Close clinical inspection of the patient upon admission

Correspondence to: Nenad Koruga, $M D$, Osijek University Hospital Center, Department of Neurosurgery, J. Huttlera 4, HR-31000 Osijek, Croatia

E-mail: nkoruga@gmail.com

Received November 3, 2018, accepted November 27, 2018 and meticulous radiographic exams excluded the possible injuries of the vascular structures and aerodigestive tract. Despite the mechanism of injury, the proximity of the knife blade to the vertebral artery and common carotid artery carried a significant risk of vascular injury.

\section{Case Report}

A 45-year-old male patient was admitted to the emergency unit due to the posterior stab wound of the neck (Fig. 1). The knife was directed diagonally from the left to the right side of the neck. Upon admission, the patient was fully conscious, with pain and numbness along the upper right extremity. The patient underwent computerized tomography $(\mathrm{CT})$ and $\mathrm{CT}$ angiography (CTA) scan of the neck, which revealed the knife blade piercing the left-sided neck muscles and through 
the intervertebral ligaments of $\mathrm{C} \mathrm{IV/C} \mathrm{V}$ in direction to the contralateral common carotid artery, vertebral artery and cervical nerve roots (Figs. 2 and 3). According to radiographs, the patient underwent an urgent surgery. The second penetrating wound inflicted by knife was located in the left-sided supraclavicular region. Postoperatively, the patient had reduced muscle strength of the deltoid muscle (2/5) and reduced muscle strength of the triceps muscle (4/5). Muscle strength of other

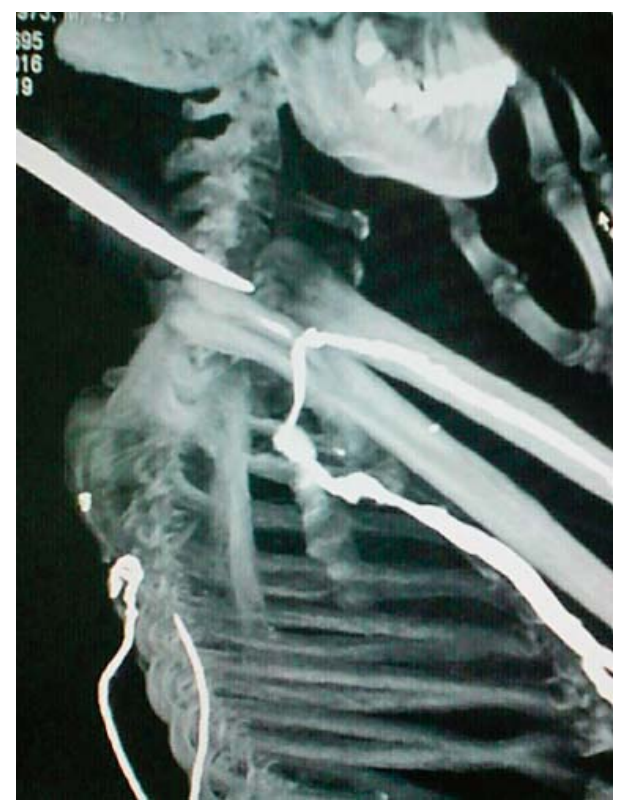

Fig. 1. Upon admission, the patient underwent radiographic scanning, which revealed the trajectory of the knife. muscle groups remained intact (5/5). According to these injuries and possible injury of the right-sided $\mathrm{C} 5$ root, the patient underwent a magnetic resonance imaging (MRI) scan, which revealed intact brachial plexus bundles at both sites of injuries. Electromyography was performed one month after surgery and revealed an acute lesion of the right-sided C5 nerve root. During the six-month postoperative follow-up, the symptoms of reduced muscle strength and the limited range of motion of the upper right extremity significantly improved. The patient was lost for further follow-up because he moved abroad.

\section{Discussion}

Penetrating neck injuries are a very rare entity of all trauma injuries at our Department. Posterior penetrating wound of the neck inflicted by low-velocity objects is a rare condition.

The higher possibility of life-threatening injuries of the neck is closely related to the anatomy distribution of vital structures and its close relationship. It is increasing the overall mortality rate after PNI, which may reach up to $11 \% \%^{5,6}$. According to anatomic distribution of vital structures in the neck, Monson et al. divided the anatomic region of the neck into three anatomy zones. Zone 2 is located between the angle of the jaw and the cricothyroid membrane, which is most prone to injury, followed by zones 1 and 3 located caudally and cranially to zone 2 , respectively ${ }^{7}$. The latter description refers to PNI inflicted on ventrodorsal axis, which alleviates assessment of vascular and aerodigestive tract and sur-

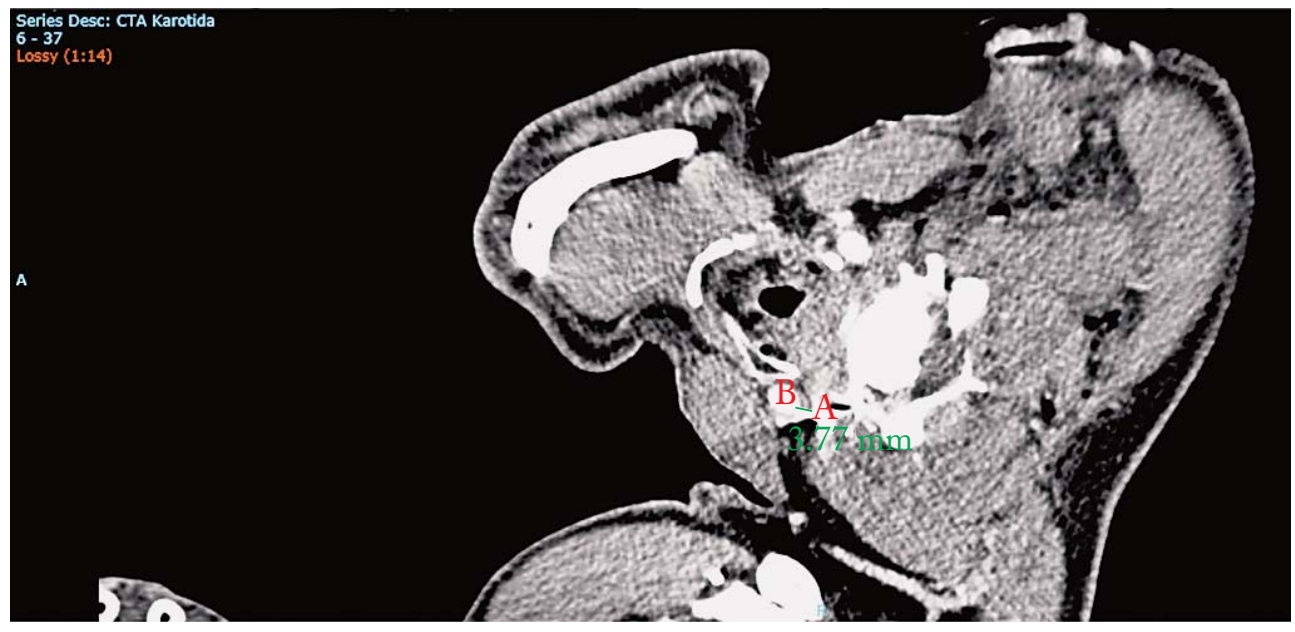

Fig. 2. Computed tomography angiography: distance from the tip of the blade (A)

to the right-sided common carotid artery (B) equals 3.77 millimeters. 


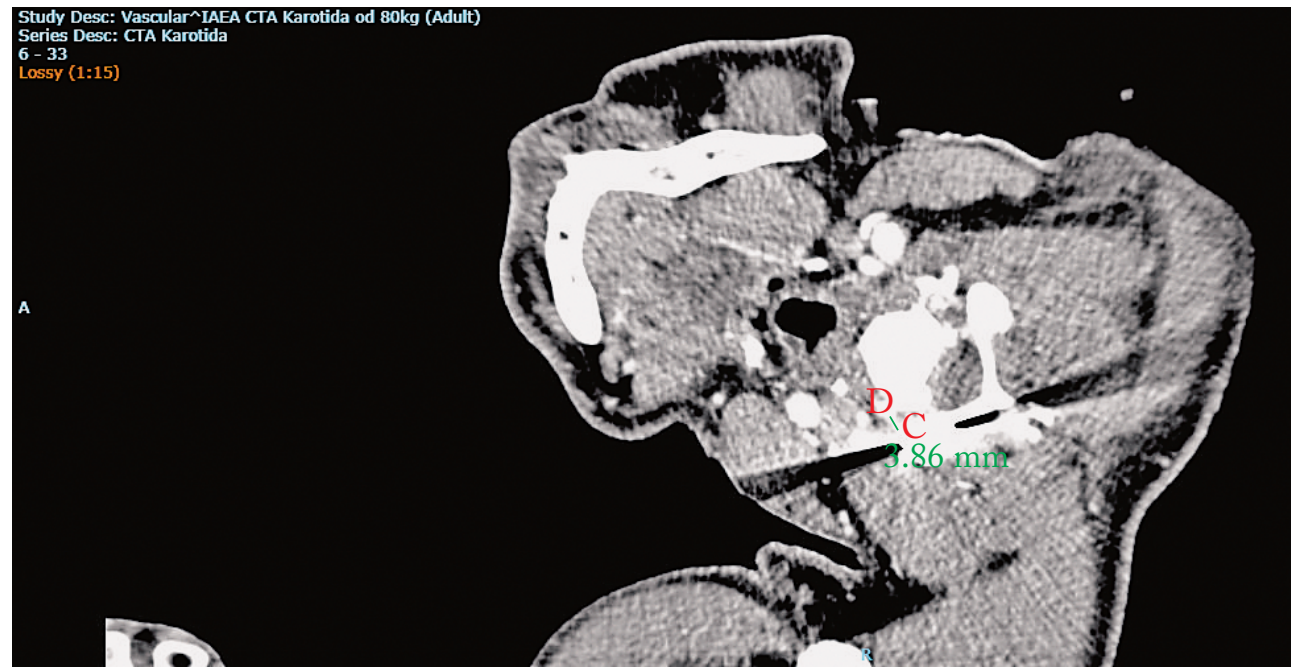

Fig. 3. Computed tomography angiography: distance from the tip of the blade $(C)$ to the right-sided vertebral artery (D) equals 3.86 millimeters.

gical approach. In such injuries, the internal jugular vein (9\%) and the carotid artery (6.7\%) are the most commonly injured vascular structures of the neck according to the study by McConnell and Trunkey, while the esophagus and trachea tract remain the most commonly injured organs of the neck ${ }^{8}$.

In our case, the patient suffered from unusual posterior neck injury, which cannot be compared to the more usual anterior injuries of the neck and 'zonal' distribution. However, according to radiographs, an injury was inflicted in unusual dorsoventral axis with a blade positioned in the diagonal trajectory with the knife blade tip close to the right-sided vertebral artery and common carotid artery (Figs. 2 and 3). In such injuries, traditional zonal approaches may not be applicable, although respect to the zonal anatomy distribution remains the only reasonable option. Muscle layers of the posterior neck region, along with solid cervical vertebrae and spinal ligaments, were fundamental to withhold the tip of the blade and prevent a larger scale of injury. It was a certain advantage in comparison with the anterior penetrating neck traumas, which are more prone to life-threatening injuries due to soft tissues and concomitant anatomic frailty. After initial assessment and preoperative management, the authors conducted surgical procedure at the site of injury. Removal of the knife without any sufficient moves, exploration of the wound and debridement were performed. The second wound inflicted in the left-sided supraclavicular region was surgically treated in the same fashion. The preop- erative role of imaging and its evaluation is crucial to determine wound trajectory and to identify structures at risk of injury in $\mathrm{PNI}^{9}$. In conclusion, prompt preoperative radiologic assessment and exclusion of injuries of vital structures in the neck with close neck inspection should be regarded as the gold standard in such lifethreatening injuries.

\section{References}

1. Vishwanatha B, Sagayaraj A, Shalini GH, Kumar P, Datta RK. Penetrating neck injuries. Indian J Otolaryngol Head Neck Surg. 2007;59:221-4. DOI: 10.1007/s12070-007-0065-7

2. Sperry JL, Moore EE, Coimbra R, et al. Western Trauma Association critical decisions in trauma: penetrating neck trauma. J Trauma Acute Care Surg. 2013;75:936-40. DOI: 10.1097/TA.0b013e31829e20e3

3. Fischer JE, Bland KI, Callery MP. Mastery of Surgery. Philadelphia, PA, USA: Lippincott Williams \& Wilkins; 2007.

4. Rhee P, Kuncir EJ, Johnson L, et al. Cervical spine injury is highly dependent on the mechanism of injury following blunt and penetrating assault. J Trauma. 2006;61(1):166-70. DOI: 10.1097/01.ta.0000188163.52226.97

5. Dr. Quinn's Online Textbook of Otolaryngology: Penetrating Neck Trauma. Grand Rounds Archive; 1995.

6. Nason RW, Assuras GN, Gray PR, Lipschitz J, Burns CM. Penetrating neck injuries: analysis of experience from a Canadian trauma centre. Can J Surg. 2001;44:122-6.

7. Monson DO, Saletta JD, Freeark RJ. Carotid vertebral trauma. J Trauma. 1969;9:987-99.

8. McConnell DB, Trunkey DD. Management of penetrating trauma of the neck. Adv Surg. 1994;71:97-127.

9. Steenburg SD, Sliker CW, Shanmuganathan K, et al. Imaging of penetrating neck injuries. RadioGraphics. 2010;30:869-86. DOI: 10.1148/rg.304105022 
Sažetak

\section{STRAŽNJA UBODNA OZLJEDA VRATA: PRIKAZ SLUČAJA}

\section{N. Koruga, A. Soldo Koruga, S. Butković Soldo i G. Kondža}

Muškarac u dobi od 45 godina primljen je u Objedinjeni hitni prijam zbog stražnje ubodne rane vrata. Oštrica noža bila je dijagonalnog usmjerenja od lijeve prema desnoj strani vrata u dorzo-ventralnoj osovini. Pri prijmu je bolesnik bio prisvjestan, žalio se na bol i trnce desnog gornjeg ekstremiteta. Učinjena je kompjutorizirana tomografija (CT) i CT angiografska obrada vrata kojima se verificira položaj noža koji penetrira lijevostranu vratnu muskulaturu i intervertebralne ligamente u segmentu C IV/C V, usmjeren prema kontralateralnoj zajedničkoj karotidnoj arteriji, vertebralnoj arteriji te korijenu živca C5. Učinjen je hitan operacijski zahvat. Tijekom ranog poslijeoperacijskog razdoblja učinjena je elektroneuromiografija kojom se dokazala akutna lezija korijena C5 desno. Poslijeoperacijskim nalazom magnetske rezonancije verificiran je intaktni brahijalni pleksus na strani ozljede. Kliničkom slikom u poslijeoperacijskom tijeku dominirala je smanjena mišićna snaga i limitirani pokreti desnog gornjeg ekstremiteta. Ubodne ozljede vrata predstavljaju rijetku kliničku patologiju s obzirom na sve slučajeve traumatskih ozljeda. Pravodobna prijeoperacijska radiološka obrada pokazala je blizinu oštrice noža spram desne vertebralne i desne zajedničke karotidne arterije. Tijekom poslijeoperacijskog boravka u kliničkoj slici zaostala je limitirana abdukcija desnog ramena kao posljedica ozljede korijena živca C5.

Ključne riječi: Vratne ozljede; Radikulopatija; Znakovi i simptomi; Rane, ubodne; Prikazi slučaja 